\title{
Probable ATP-Dependent RNA Helicase DDX20
}

National Cancer Institute

\section{Source}

National Cancer Institute. Probable AT P-Dependent RNA Helicase DDX20. NCI

Thesaurus. Code C118357.

Probable ATP-dependent RNA helicase DDX20 (824 aa, 92 kDa) is encoded by the human DDX20 gene. This protein is involved in spliceosome formation and ATP hydrolysis. 